\title{
Razine sumporovodika, amonijaka i merkaptana u zraku na području Centralnog uređaja za pročišćavanje otpadnih voda grada Zagreba
}

\author{
V. Gluščić* M. Šilović Hujić, I. Bešlić, S. Davila i G. Pehnec \\ Institut za medicinska istraživanja i medicinu rada, Ksaverska cesta 2, 10000 Zagreb, Hrvatska
}

https://doi.org/10.15255/KUI.2020.026

$\mathrm{KUI}-53 / 2020$

Izlaganje sa znanstvenog skupa

Prispjelo 21. travnja 2020.

Prihvaćeno 16. srpnja 2020.

\begin{abstract}
Sažetak
Na području Centralnog uređaja za pročišćavanje otpadnih voda grada Zagreba (CUPOVZ) od 2004. godine provode se ciljana mjerenja imisijskih koncentracija sumporovodika $\left(\mathrm{H}_{2} \mathrm{~S}\right)$, amonijaka $\left(\mathrm{NH}_{3}\right)$ i ukupnih merkaptana $(\mathrm{R}-\mathrm{SH})$. $\mathrm{U}$ ovom radu prikazani su rezultati mjerenja provedenih tijekom 2017. godine na dvije mjerne postaje: Biologija-sjever i Biologija-jug, koje su smještene u krugu CUPOVZ-a. 24-satni uzorci $\mathrm{H}_{2} \mathrm{~S}, \mathrm{NH}_{3}$ i R-SH sakupljani su po mjesec dana u svakom godišnjem dobu. Koncentracije $\mathrm{H}_{2} \mathrm{~S}, \mathrm{NH}_{3}$ i R-SH na obje mjerne postaje pokazuju statistički značajnu sezonsku ovisnost $(p<0,05)$. Promatrajući sva mjerna razdoblja zajedno, pronađene su visoke pozitivne korelacije između svih onečišćujućih tvari i temperature te negativne $s$ tlakom.

Ključne riječi

Uređaj za pročišćavanje otpadnih voda, mjerna postaja, imisije, granična vrijednost, sezonske razlike, korelacije
\end{abstract}

\section{Uvod}

Zagreb je glavni i najveći grad Republike Hrvatske s oko 800000 stanovnika, površine oko $640000 \mathrm{~km}^{2}$ te 17 gradskih četvrti i 218 mjesnih odbora. Nalazi se na raskrižju putova između srednje i jugoistočne Europe. Smješten je na obroncima Medvednice i proteže se s obje strane rijeke Save. ${ }^{1}$

Krajem 19. st. na sjevernoj obali rijeke Save započela je izgradnja kanalizacijske mreže grada Zagreba, koja je 1956. godine, prilikom izgradnje Zagrebačkog Velesajma, povezana s južnom obalom rijeke Save sustavom javne odvodnje. Sustav javne odvodnje izgrađen je za prihvat otpadnih i oborinskih voda s ispustima u rijeku Savu. ${ }^{2}$

Pojam otpadnih voda obuhvaća sve vode koje su uporabom promijenile svoj prvobitni sastav, odnosno svoje fizikalne, kemijske i biološke karakteristike. Sve potencijalno onečišćene tehnološke, kućanske, oborinske i druge vode sudjeluju u hidrološkom ciklusu te se nakon prvobitne uporabe kanalizacijskim sustavom odvode na pročišćavanje kako bi se iz njih do određenog stupnja uklonile plivajuće, lebdeće i otopljene tvari i smanjio njihov nepovoljan utjecaj na okoliš. ${ }^{3}$

U drugoj polovici 20. stoljeća uslijed brzog gospodarskog razvoja grada Zagreba i prekomjernog ispuštanje nepročišćenih komunalnih otpadnih voda, a posebice industrijskih u rijeku Savu, utvrđeno je narušavanje kvalitete vode rijeke Save nizvodno od ušća glavnog odvodnog kanala. Sve stroži zahtjevi europskog i hrvatskog zakonodavstva iz područja zaštite okoliša (voda, tlo i zrak) doveli su do toga da Grad Zagreb i Hrvatske vode 2003. godine pokrenu Projekt izgradnje Centralnog uređaja za pročišćavanje otpadnih voda (CUPOVZ), kao uobičajenu i neizbježnu mjeru zaštite voda. Proces pročišćavanja otpadnih voda obuhvaća dva glavna stupnja: mehaničko pročišćavanje otpadnih voda upotrebom grubih i finih rešetki te biološko pročišćavanje otpadnih voda $\mathrm{s}$ pripadajućom obradom nastalog mulja. ${ }^{2,4}$

Projektom CUPOVZ obuhvaćena je izgradnja sedam infrastrukturnih objekata prikazanih na slici 1 u istočnom dijelu Zagreba. To je jedan od najvećih ekoloških zahvata u Europi u svrhu rješavanja problema zagađenja i ugroženosti podzemnih voda i vodocrpilišta na području grada Zagreba te na dijelu toka rijeke Save nizvodno od Zagreba. $^{2}$

Prilikom procesa obrade otpadnih voda može doći do stvaranja različiti plinovitih onečišćujućih tvari koje svojim neugodnim mirisom mogu narušiti kvalitetu življenja lokalnog stanovništva (dodijavanje mirisima). Zagrebačke otpadne vode Upravljanje i pogon d.o.o. uspostavile su lokalnu mjernu mrežu za ciljana mjerenja imisijskih koncentracija sumporovodika $\left(\mathrm{H}_{2} \mathrm{~S}\right)$, amonijaka $\left(\mathrm{NH}_{3}\right)$ i merkaptana $(\mathrm{R}-\mathrm{SH})$ u svrhu kontrole kvalitete zraka na području pročišćivača i praćenja utjecaja na okoliš. 


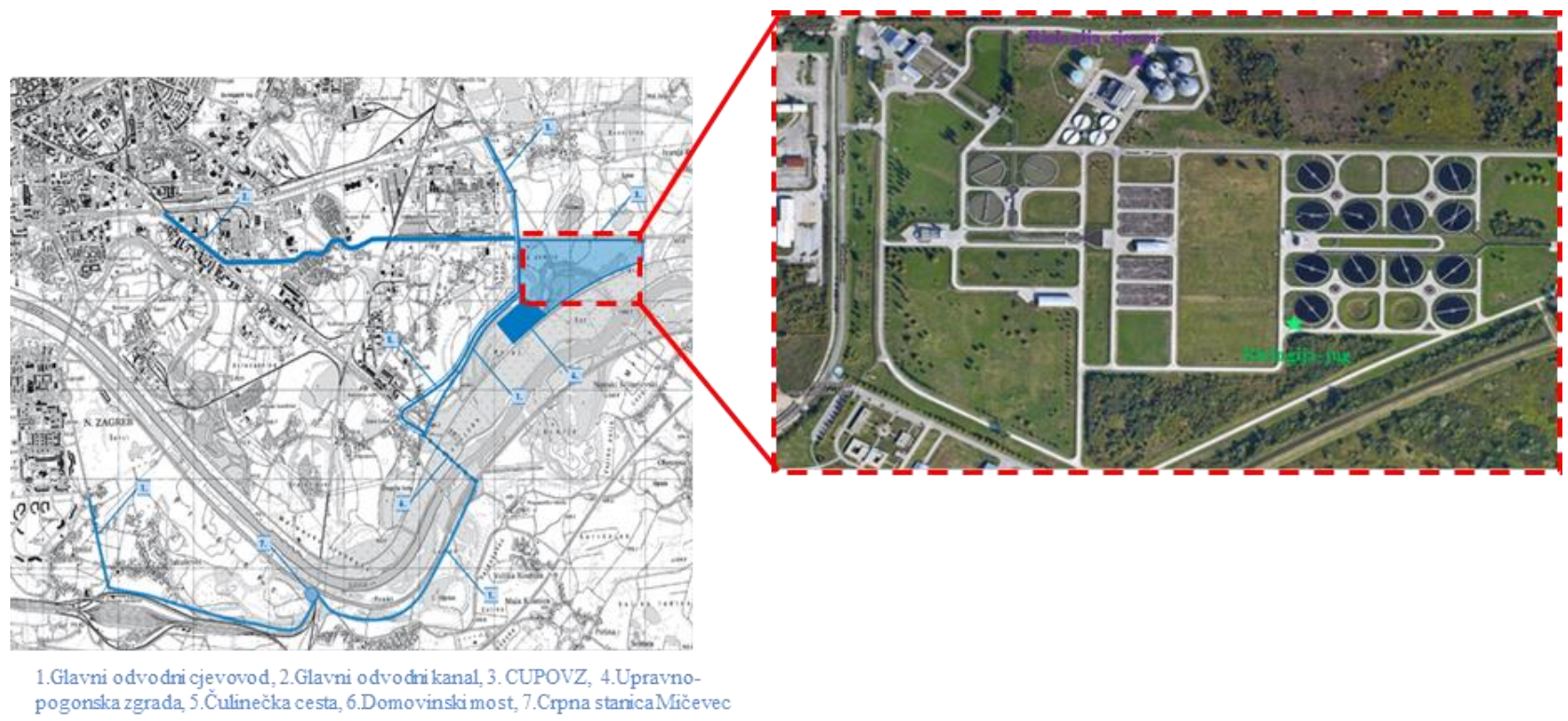

Slika 1 - Položaj infrastrukturnih objekata Projekta CUPOVZ u gradu Zagrebu i mjernih postaja Biologija-sjever i Biologija-jug unutar kompleksa CUPOVZ-a

Fig. 1 - CUPOVZ Project infrastructure facilities location in Zagreb and measuring sites Biology-north and Biology-south within the CWWTZ area

$\mathrm{U}$ ovom radu prikazani su rezultati mjerenja masenih koncentracija $\mathrm{H}_{2} \mathrm{~S}, \quad \mathrm{NH}_{3}$ i $\mathrm{R}-\mathrm{SH}$ te meteoroloških parametara na dvije mjerne postaje unutar kompleksa CUPOVZ, gdje se odvija biološko pročišćavanje otpadnih voda, provedenih po 30 dana u svakom godišnjem dobu tijekom 2017. godine, koji su dio Izvještaja o praćenju kvalitete zraka u zoni utjecaja CUPOVZ-a u Zagrebu. ${ }^{12}$ Ispitana je sezonska ovisnost izmjerenih koncentracija plinovitih onečišćujućih tvari kao i njihova korelacija s meteorološkim parametrima.

\section{Eksperimentalni dio}

24-satni uzorci sumporovodika $\left(\mathrm{H}_{2} \mathrm{~S}\right)$, amonijaka $\left(\mathrm{NH}_{3}\right)$ i ukupnih merkaptana $(\mathrm{R}-\mathrm{SH})$ sakupljani su kontinuirano po mjesec dana u svakom godišnjem dobu u 2017. godini na mjernim postajama Biologija-sjever i Biologija-jug unutar kompleksa CUPOVZ. Razdoblja mjerenja u svakom godišnjem dobu navedena su u tablici 1. Mjerne postaje klasificirane su kao industrijske u odnosu na izvor emisija. Položaj mjernih postaja prikazan je na slici 1 .

Tablica 1 - Razdoblja mjerenja u svakom godišnjem dobu Table 1 - Measurement periods in each season

\begin{tabular}{l|c|c|}
\hline Godišnje doba & Oznaka sezone & Razdoblja mjerenja \\
\hline zima & Z & $15.2 .-18.3 .2017$. \\
\hline proljeće & $\mathrm{P}$ & $10.4 .-10.5 .2017$. \\
\hline ljeto & LJ & $10.7 .-09.8 .2017$. \\
\hline jesen & $\mathrm{J}$ & $10.10 .-12.11 .2017$.
\end{tabular}

Uzorci $\mathrm{NH}_{3}$ sakupljani su prosisavanjem zraka $\mathrm{u}$ apsorpcijsku otopinu $0,06 \%$ vodikova peroksida $\left(\mathrm{H}_{2} \mathrm{O}_{2}\right)$. Masene koncentracije $\mathrm{NH}_{3}$ određene su spektrofotometrijski Nesslerovom metodom ${ }^{5}$ upotrebom Cecil 9200 spektrofotometra proizvođača Super Aquarius. Uzorci $\mathrm{H}_{2} \mathrm{~S}$ i $\mathrm{R}-\mathrm{SH}$ sakupljani su prosisavanjem zraka na impregnirani filtarski medij. Za uzorkovanje $\mathrm{H}_{2} \mathrm{~S}$ filtar-papir Whatman No. 41 impregniran je živinim(II) kloridom uz dodatak uree kao antioksidansa, a koncentracija $\mathrm{H}_{2} \mathrm{~S}$ u uzorku određena je spektrofotometrijskom metodom molibdenskog plavila. ${ }^{6,7}$ Kod sakupljanja i određivanja merkaptana, sumporovodik interferira, pa se mora prethodno ukloniti. Zbog toga su impregnirani filtri u držaču uvijek bili spojeni u seriju i to tako da je u prvom držaču bio impregnirani filtar za sakupljanje $\mathrm{H}_{2} \mathrm{~S}$, a u drugom za sakupljanje $\mathrm{R}-\mathrm{SH}$. Merkaptani su sakupljani na filtar-papir Whatman No. 41 impregniran živinim(II) acetatom uz dodatak octene kiseline, a koncentracija $\mathrm{R}-\mathrm{SH}$ u uzorku određena je spektrofotometrijski pomoću $N, N$ dimetil $p$-fenilendiamin hidroklorida i Reissnerova reagensa. ${ }^{8}$ Tom metodom određuju se ukupni merkaptani, a rezultati su izraženi kao merkaptanski sumpor $\mathrm{R}-\mathrm{SH}$. Meteorološki parametri mjereni su automatskom mjernom postajom Davis vantage PRO2. Izračunate su satne vrijednosti temperature, tlaka i relativne vlažnosti zraka. $\mathrm{Na}$ osnovi dnevnih srednjaka satnih vrijednosti praćena je promjena temperature, tlaka i relativne vlažnosti zraka, a rezultati su prikazani grafički. Na osnovi vrijednosti smjera i brzine vjetra u 7, 14 i 21 sat određivani su učestalost smjera vjetra i srednje brzine vjetra po smjerovima te su prikazani ružom vjetra. 


\section{Rezultati i rasprava}

U tablicama 2-4 za mjerne postaje Biologija-sjever i Biologija-jug tijekom sva četiri mjerna razdoblja u 2017. godini prikazani su statistički parametri: $\mathrm{N}$ - broj uzoraka, $\mathrm{C} \pm \mathrm{STD}$ - srednja vrijednost \pm standardno odstupanje; $C_{\min }$ - najniža izmjerena koncentracija; $C_{\max }-$ najviša izmjerena koncentracija; $\mathrm{C}_{50}$ - medijan; $\mathrm{C}_{98}-98$.percentil izmjerenih masenih koncentracija $\mathrm{H}_{2} \mathrm{~S}, \mathrm{R}-\mathrm{SH}$ i $\mathrm{NH}_{3} \mathrm{i}$ $\mathrm{N}>\mathrm{GV}$ - broj dana s koncentracijom onečišćujuće tvari većom od granične vrijednosti.

Dnevne (24-satne) masene koncentracije $\mathrm{H}_{2} \mathrm{~S}$ na mjernoj postaji Biologija-sjever kretale su se $\mathrm{u}$ rasponu od $0,58 \mu \mathrm{g} \mathrm{m}^{-3}$ do $11,06 \mu \mathrm{gm}^{-3}$, a na mjernoj postaji

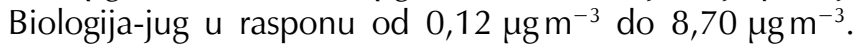
Najviša srednja vrijednost koncentracija $\mathrm{H}_{2} \mathrm{~S}$ izmjerena je u zimskom razdoblju mjerenja na mjernoj postaji Biologijasjever, a u jesen na mjernoj postaji Biologija-jug.

Uredba o razinama onečišćujućih tvari u zraku ${ }^{9}$ propisuje granične vrijednosti (GV) i ciljne vrijednosti za određene onečišćujuće tvari u vanjskom zraku. Za onečišćujuće tvari $\mathrm{H}_{2} \mathrm{~S}, \mathrm{NH}_{3}$ i R-SH granične vrijednosti zadane su s obzirom na kvalitetu življenja (dodijavanje mirisima), a ne s obzirom na zaštitu zdravlja ljudi. Za te onečišćujuće tvari prag mirisa je kod ljudi vrlo nizak i višestruko je niži od razina kod kojih bi mogli nastati eventualni štetni zdravstveni učinci. $\mathrm{Na}$ primjer, Svjetska zdravstvena organizacija ${ }^{10}$ daje smjernicu za $\mathrm{H}_{2} \mathrm{~S}$ u zraku od $150 \mu \mathrm{g} \mathrm{m}^{-3}$ s obzirom na zaštitu zdravlja, dok je u propisima Republike Hrvatske sa stanovišta izazivanja neugodnih mirisa propisana 30 puta niža granična vrijednost - prema Uredbi GV-a za $\mathrm{H}_{2} \mathrm{~S}$ za vrijeme usrednjavanja $24 \mathrm{~h}$ iznosi $5 \mu \mathrm{gm}^{-3}$ te ne smije biti prekoračena više od sedam puta tijekom kalendarske godine. Iz rezultata u tablici 2 vidljivo je da su 24-satne vrijednosti koncentracija $\mathrm{H}_{2} \mathrm{~S}$ na obje mjerne postaje $\mathrm{u}$ zimskom i jesenskom razdoblju povremeno prekoračivale propisan dopušteni GV, odnosno da je u 2017. godini povremeno dolazilo do dodijavanja neugodnim mirisom sumporovodika. Na mjernoj postaji Biologija-sjever do prekoračenja je došlo šest puta tijekom zime i pet puta tijekom jeseni, a na mjernoj postaji Biologija-jug dva puta tijekom zime i jednom tijekom jeseni (slika 2). Sličan broj prekoračenja GV-a na mjernoj postaji Biologija-sjever primijećen je 2005. godine. ${ }^{11}$ Iz Izvještaja o praćenju kvalitete zraka u zoni utjecaja CUPOVZ-a ${ }^{12,13}$ u Zagrebu može se vidjeti da se broj dana s prekoračenjima razlikuje od godine do godine te da vrijednosti iz 2017. godine ne odstupaju značajnije od ranijih godina.

Dnevne masene koncentracije R-SH tijekom 2017. godine na mjernoj postaji Biologija-sjever kretale su se u rasponu do 2,76 $\mathrm{gg} \mathrm{m}^{-3}$, a na mjernoj postaji Biologija-jug do $3,88 \mu \mathrm{g} \mathrm{m}^{-3}$. Najviša srednja vrijednost R-SH izmjerena je u jesen na mjernoj postaji Biologija-sjever, odnosno u zimi na mjernoj postaji Biologija-jug (tablica 3). Uredbom je propisan GV za R-SH od $3 \mu \mathrm{g} \mathrm{m}^{-3}$ za 24-satni prosjek i ne smije biti prekoračen više od sedam puta tijekom kalendarske godine. Masene koncentracije merkaptana prekoračile su GV dva puta u zimskom razdoblju mjerenja (slika 3) na mjernoj postaji Biologija-jug, dok na mjernoj postaji Biologija-sjever nije dolazilo do prekoračenja GV-a. Slični rezultati na obje mjerne postaje izmjereni su i 2012. godine u istraživanju Godec i sur. ${ }^{14}$ Koncentracije $\mathrm{R}-\mathrm{SH}$ u 2017. godini u rasponu su vrijednosti iz ranijih godina. ${ }^{13}$

Tablica 2 - Osnovni statistički podatci 24-satnih masenih koncentracija $\mathrm{H}_{2} \mathrm{~S}\left(\mu \mathrm{g} \mathrm{m}^{-3}\right)$

Table 2 - Basic statistics data of $\mathrm{H}_{2} \mathrm{~S} 24$-hour mass concentrations $\left(\mu \mathrm{g} \mathrm{m}^{-3}\right)$

\begin{tabular}{|c|c|c|c|c|c|c|c|c|}
\hline Mjerna postaja & Sezona & $\mathrm{N}$ & $\mathrm{C} \pm \mathrm{STD}$ & $\mathrm{C}_{\min }$ & $\mathrm{C}_{\max }$ & $\mathrm{C}_{50}$ & $\mathrm{C}_{98}$ & $\mathrm{~N}>\mathrm{GV}$ \\
\hline \multirow{4}{*}{ Biologija-sjever } & Z & 32 & $3,68 \pm 2,25$ & 1,31 & 11,06 & 2,74 & 10,78 & 6 \\
\hline & $\mathrm{P}$ & 31 & $2,21 \pm 0,63$ & 1,17 & 3,24 & 2,23 & 3,20 & 0 \\
\hline & LJ & 31 & $1,87 \pm 0,83$ & 0,58 & 4,76 & 1,69 & 3,90 & 0 \\
\hline & $J$ & 34 & $3,34 \pm 1,79$ & 1,17 & 8,77 & 3,07 & 7,53 & 5 \\
\hline \multirow{4}{*}{ Biologija-jug } & Z & 32 & $1,56 \pm 1,51$ & 0,12 & 6,77 & 1,04 & 6,31 & 2 \\
\hline & $\mathrm{P}$ & 31 & $0,64 \pm 0,26$ & 0,20 & 1,14 & 0,61 & 1,14 & 0 \\
\hline & LJ & 31 & $0,64 \pm 0,35$ & 0,18 & 1,56 & 0,56 & 1,56 & 0 \\
\hline & J & 34 & $1,76 \pm 1,44$ & 0,23 & 8,70 & 1,53 & 5,21 & 1 \\
\hline
\end{tabular}

$\mathrm{N}$ - broj uzoraka; $\mathrm{C} \pm \mathrm{STD}$ - srednja vrijednost \pm standardno odstupanje; $C_{\min }$ - najniža izmjerena koncentracija; $C_{\max }-$ najviša izmjerena koncentracija; $C_{50}$ - medijan; $C_{98}-98$. percentil; $N>G V-$ broj dana s koncentracijom većom od granične vrijednosti $\left(5 \mu g \mathrm{~m}^{-3}\right)$ 
Tablica 3 - Osnovni statistički podatci 24-satnih masenih koncentracija $\mathrm{R}-\mathrm{SH}\left(\mu \mathrm{g} \mathrm{m}^{-3}\right)$

Table 3 - Basic statistics data of R-SH 24-hour mass concentrations $\left(\mu \mathrm{g} \mathrm{m}^{-3}\right)$

\begin{tabular}{|c|c|c|c|c|c|c|c|c|}
\hline Mjerna postaja & Sezona & $\mathrm{N}$ & $\mathrm{C} \pm \mathrm{STD}$ & $C_{\min }$ & $C_{\max }$ & $\mathrm{C}_{50}$ & $\mathrm{C}_{98}$ & $\mathrm{~N}>\mathrm{GV}$ \\
\hline \multirow{4}{*}{ Biologija-sjever } & Z & 32 & $0,63 \pm 0,46$ & 0,07 & 2,02 & 0,60 & 1,87 & 0 \\
\hline & $P$ & 31 & $0,69 \pm 0,36$ & 0,00 & 1,85 & 0,65 & 1,60 & 0 \\
\hline & LJ & 31 & $0,46 \pm 0,32$ & 0,00 & 1,59 & 0,48 & 1,20 & 0 \\
\hline & $J$ & 34 & $0,83 \pm 0,89$ & 0,00 & 2,76 & 0,46 & 2,66 & 0 \\
\hline \multirow{4}{*}{ Biologija-jug } & Z & 32 & $0,76 \pm 0,85$ & 0,00 & 3,88 & 0,65 & 3,57 & 2 \\
\hline & $\mathrm{P}$ & 31 & $0,74 \pm 0,26$ & 0,26 & 1,22 & 0,68 & 1,20 & 0 \\
\hline & LJ & 31 & $0,44 \pm 0,22$ & 0,00 & 0,81 & 0,47 & 0,77 & 0 \\
\hline & $J$ & 34 & $0,74 \pm 0,90$ & 0,00 & 2,90 & 0,19 & 2,72 & 0 \\
\hline
\end{tabular}

$\mathrm{N}$ - broj uzoraka; $\mathrm{C} \pm \mathrm{STD}$ - srednja vrijednost \pm standardno odstupanje; $C_{\min }$ - najniža izmjerena koncentracija; $C_{\max }-$ najviša izmjerena koncentracija; $\mathrm{C}_{50}$ - medijan; $\mathrm{C}_{98}$ - 98. percentil; $\mathrm{N}>\mathrm{GV}$ - broj dana s koncentracijom većom od granične vrijednosti $\left(3 \mu \mathrm{g} \mathrm{m}^{-3}\right)$

Tablica 4 - Osnovni statistički podatci 24-satnih masenih koncentracija $\mathrm{NH}_{3}\left(\mu \mathrm{g} \mathrm{m}^{-3}\right)$

Table 4 - Basic statistics data of $\mathrm{NH}_{3}$ 24-hour mass concentrations $\left(\mu \mathrm{g} \mathrm{m}^{-3}\right)$

\begin{tabular}{|c|c|c|c|c|c|c|c|c|}
\hline Sezona & $\mathrm{N}$ & $\mathrm{C} \pm \mathrm{STD}$ & $C_{\text {min }}$ & $C_{\max }$ & $\mathrm{C}_{50}$ & $\mathrm{C}_{98}$ & $\mathrm{~N}>\mathrm{GV}$ & Sezona \\
\hline \multirow{4}{*}{ Biologija-sjever } & Z & 32 & $10,79 \pm 4,76$ & 5,03 & 22,82 & 9,69 & 21,79 & 0 \\
\hline & $\mathrm{P}$ & 31 & $9,11 \pm 6,89$ & 0,66 & 39,74 & 7,51 & 27,58 & 0 \\
\hline & LJ & 31 & $10,17 \pm 4,04$ & 2,56 & 23,19 & 9,78 & 19,76 & 0 \\
\hline & $J$ & 33 & $7,54 \pm 3,04$ & 0,86 & 17,43 & 7,30 & 14,29 & 0 \\
\hline \multirow{4}{*}{ Biologija-jug } & Z & 32 & $12,50 \pm 9,26$ & 3,71 & 52,32 & 9,56 & 36,69 & 0 \\
\hline & $\mathrm{P}$ & 31 & $8,39 \pm 3,17$ & 4,06 & 15,34 & 7,68 & 15,24 & 0 \\
\hline & LJ & 31 & $11,71 \pm 4,54$ & 6,26 & 25,30 & 10,09 & 23,45 & 0 \\
\hline & $J$ & 33 & $11,61 \pm 4,65$ & 5,35 & 25,51 & 10,85 & 21,83 & 0 \\
\hline
\end{tabular}

$\mathrm{N}$ - broj uzoraka; $\mathrm{C} \pm \mathrm{STD}$ - srednja vrijednost \pm standardno odstupanje; $C_{\min }$ - najniža izmjerena koncentracija; $C_{\max }-$ najviša izmjerena koncentracija; $\mathrm{C}_{50}$ - medijan; $\mathrm{C}_{98}$ - 98. percentil; $\mathrm{N}>\mathrm{GV}$ - broj dana s koncentracijom većom od granične vrijednosti $\left(100 \mu \mathrm{m}^{-3}\right)$

Dnevne masene koncentracije $\mathrm{NH}_{3}$ na mjernoj postaji Biologija-sjever kretale su se u rasponu od $0,66 \mu \mathrm{g} \mathrm{m}^{-3}$ do

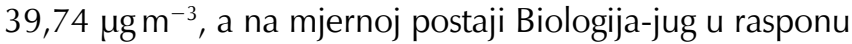
od $3,71 \mu \mathrm{g} \mathrm{m}^{-3}$ do $52,32 \mu \mathrm{g} \mathrm{m}^{-3}$. Najviša srednja vrijednost koncentracija $\mathrm{NH}_{3}$ izmjerena je na obje mjerne postaje u zimi, dok je najniža srednja vrijednost koncentracija izmjerena $u$ jesen na mjernoj postaji Biologija-sjever, odnosno, u proljeće na mjernoj postaji Biologija-jug. Rezultati pokazuju da su 24-satne koncentracije $\mathrm{NH}_{3}$ na obje mjerne postaje tijekom 2017. godine bile znatno niže od propisanog GV-a od

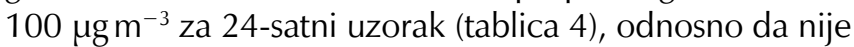
dolazilo do pojave neugodnog mirisa amonijaka. Slične vrijednosti amonijaka zabilježene su i u ranijim godinama. ${ }^{13}$
Na slikama $2-4$ uočljive su razlike u koncentracijama $\mathrm{H}_{2} \mathrm{~S}$, $\mathrm{R}-\mathrm{SH}$ i $\mathrm{NH}_{3}$ između pojedinih razdoblja mjerenja. Značajnost razlike u koncentracijama između pojedinih razdoblja mjerenja ispitana je primjenom Kruskal Wallisova testa. $\mathrm{Na}$ obje mjerne postaje izmjerene koncentracije $\mathrm{H}_{2} \mathrm{~S}, \mathrm{R}-\mathrm{SH}$ i NH $\mathrm{NH}_{3}$ statistički su se značajno razlikovale ovisno o godišnjim dobima (tablici 5). Slične statistički značajne razlike pronađene su i u prethodnom istraživanju Godec i sur. ${ }^{14}$ na istoj lokaciji.

Tijekom 2017. godine u svakom mjernom razdoblju određivani su dnevni srednjaci temperature zraka $(T)$, tlaka zraka $(p)$ i relativne vlažnosti zraka $(R V)$ na osnovi satnih vrijednosti. Srednje vrijednosti meteoroloških parametara za svako razdoblje mjerenja prikazane su u tablici 6 . 

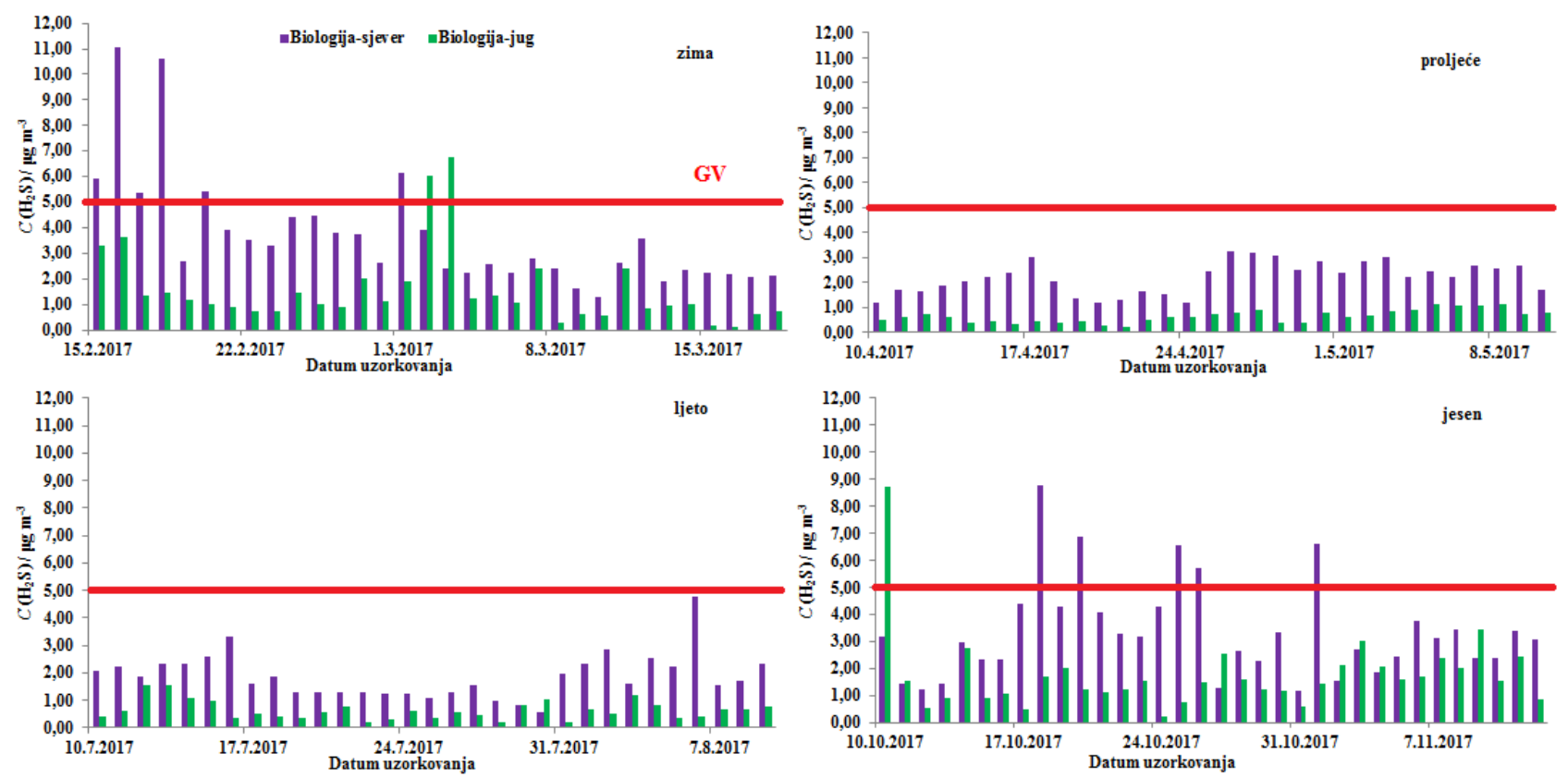

Slika 2 - Dnevne vrijednosti masenih koncentracija $\mathrm{H}_{2} \mathrm{~S}$ na mjernim postajama Biologija-sjever i Biologija-jug tijekom mjernih razdoblja u 2017. godini

Fig. 2 - Daily $\mathrm{H}_{2} \mathrm{~S}$ mass concentrations at measuring sites Biology-north and Biology-south during the measuring periods in 2017
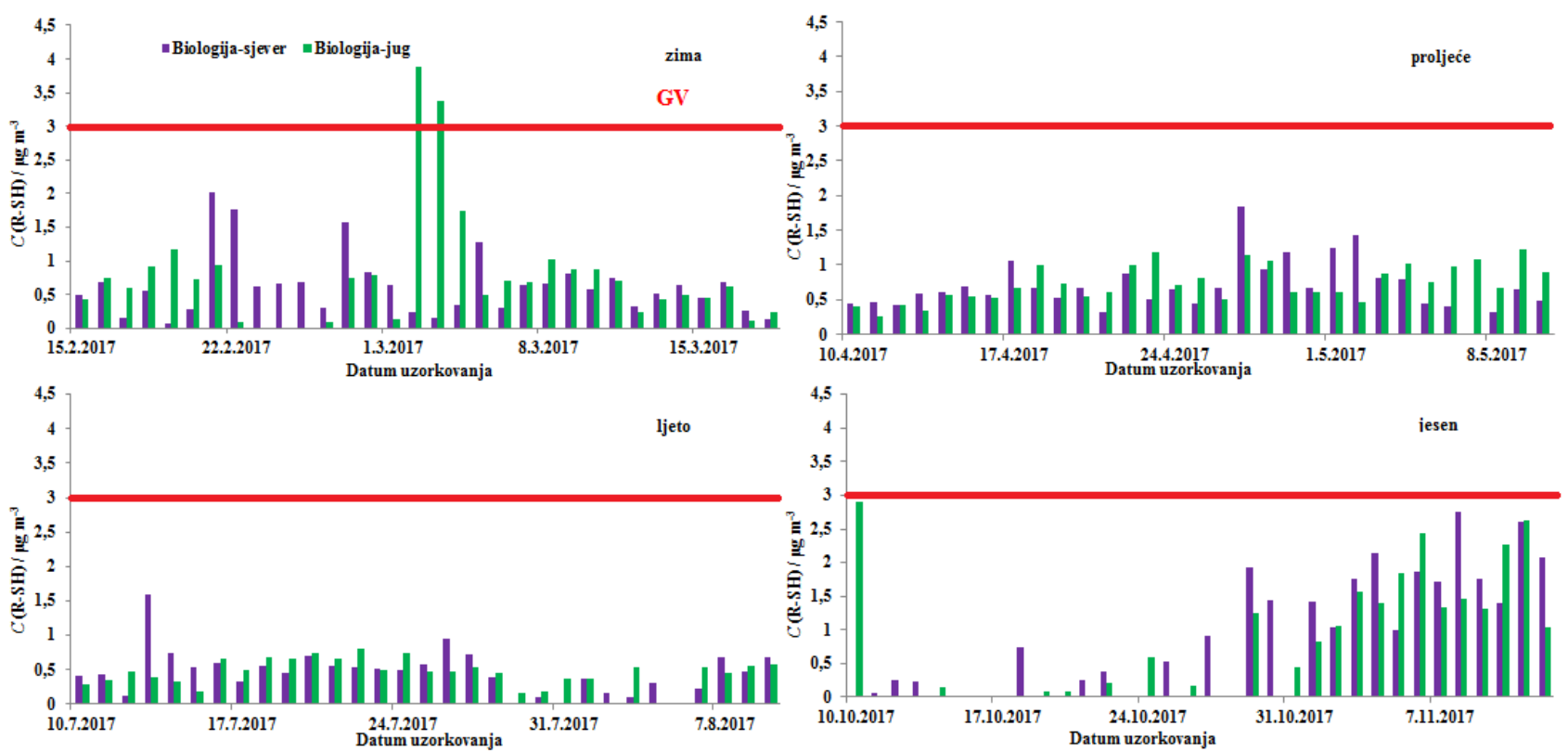

Slika 3 - Dnevne vrijednosti masenih koncentracija R-SH na mjernim postajama Biologija-sjever i Biologija-jug tijekom mjernih razdoblja u 2017. godini

Fig. 3 - Daily R-SH mass concentrations at measuring sites Biology-north and Biology-south during the measuring periods in 2017 

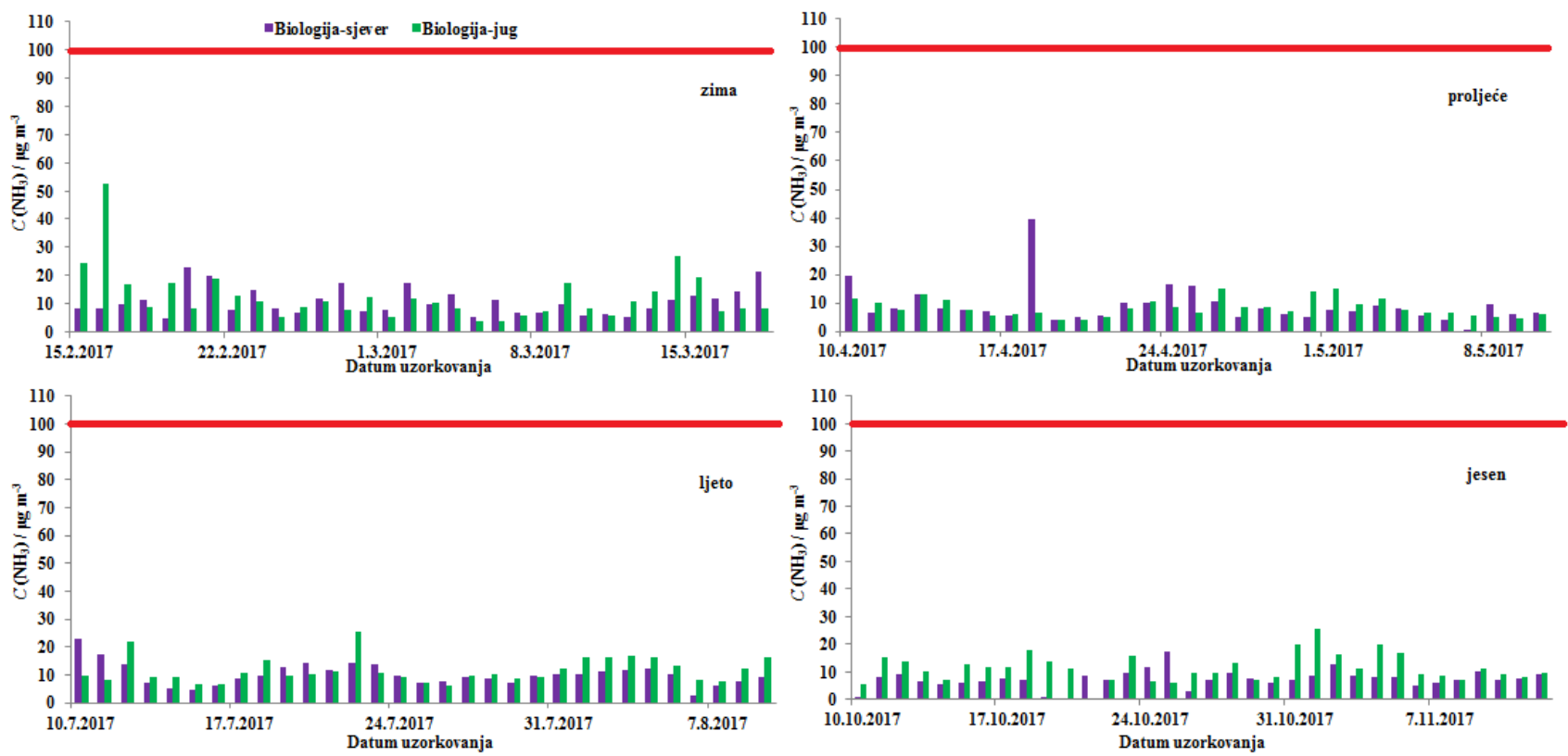

Slika 4 - Dnevne vrijednosti masenih koncentracija $\mathrm{NH}_{3}$ na mjernim postajama Biologija-sjever i Biologija-jug tijekom mjernih razdoblja u 2017. godini

Fig. 4 - Daily $\mathrm{NH}_{3}$ mass concentrations at measuring sites Biology-north and Biology-south during the measuring periods in 2017

Tablica 5 - Značajnost razlike između masenih koncentracija $\mathrm{H}_{2} \mathrm{~S}, \mathrm{R}-\mathrm{SH}$ i NH $\mathrm{N}_{3}$ izmjerenih u različitim razdobljima mjerenja Table 5 - Significance of differences between measured $\mathrm{H}_{2} \mathrm{~S}, \mathrm{R}-\mathrm{SH}$, and $\mathrm{NH}_{3}$ mass concentrations at different measuring periods

\begin{tabular}{|c|c|c|c|c|c|c|c|}
\hline \multirow[b]{2}{*}{ Mjerna postaja } & \multirow[b]{2}{*}{ Onečišćujuća tvar } & \multicolumn{6}{|c|}{ Mjerna razdoblja koja se uspoređuju } \\
\hline & & $\mathrm{Z} / \mathrm{P}$ & $\mathrm{Z} / \mathrm{LJ}$ & $\mathrm{Z} / \mathrm{J}$ & $\mathrm{P} / \mathrm{LJ}$ & $\mathrm{P} / \mathrm{J}$ & $\mathrm{LJ} / \mathrm{J}$ \\
\hline \multirow{3}{*}{ Biologija-sjever } & $\mathrm{H}_{2} \mathrm{~S}$ & + & + & - & - & - & + \\
\hline & $\mathrm{R}-\mathrm{SH}$ & - & - & - & - & - & - \\
\hline & $\mathrm{NH}_{3}$ & - & - & + & - & - & - \\
\hline \multirow{3}{*}{ Biologija-jug } & $\mathrm{H}_{2} \mathrm{~S}$ & + & + & - & - & + & + \\
\hline & $\mathrm{R}-\mathrm{SH}$ & - & - & - & + & - & - \\
\hline & $\mathrm{NH}_{3}$ & - & - & - & + & + & - \\
\hline
\end{tabular}

+ statistički se razlikuju; - statistički se ne razlikuju (Kruskal Wallisov test, $\mathrm{p}<0,05$ )

Učestalosti smjera vjetra i brzine vjetra na osnovi vrijednosti u 7, 14 i 21 sat za ista razdoblja mjerenja prikazane su na slici 5 .

Tijekom zimskog razdoblja zabilježena je najviša učestalost vjetra iz smjera sjevera uz povišene brzine vjetra iz jugoistočnih smjerova. Tijekom proljetnog razdoblja zabilježena je najviša učestalost vjetra iz smjera juga i sjevera sa zabilježenim povišenim brzinama vjetra iz smjera istok-sjeveroistok. Tijekom ljetnog razdoblja zabilježena je najviša učestalost vjetra iz smjera jugoistoka uz povišene brzine vjetra iz smjera sjevera i istokjugoistoka. Tijekom jesenskog razdoblja zabilježene su najviše učestalosti vjetra iz zapadnih i istočnih smjerova uz povišene brzine vjetra iz sjeveroistočnih smjerova.
U nastavku istraživanja ispitivana je povezanost koncentracija onečišćujućih tvari u zraku i meteoroloških parametara. Tablica 7 prikazuje vrijednosti korelacijskih koeficijenata između masenih koncentracija $\mathrm{H}_{2} \mathrm{~S}, \mathrm{R}-\mathrm{SH}$, $\mathrm{NH}_{3}$ i meteoroloških parametara.

Na mjernoj postaji Biologija-jug u zimi i u proljeće pronađena je statistički značajna pozitivna korelacija svih onečišćujućih tvari s temperaturom i relativnom vlažnosti, a značajna negativna korelacija s tlakom zraka. Ljeti je pronađena samo statistički značajna pozitivna korelacija između amonijaka i temperature, a u jesen negativna korelacija između koncentracija merkaptana i temperature i tlaka zraka. $\mathrm{Na}$ mjernoj postaji Biologija-sjever onečišćujuće tvari su znatno slabije korelirale $\mathrm{s}$ meteorološkim podatcima. 
Tablica 6 - Srednje vrijednosti meteoroloških parametara za pojedina razdoblja mjerenja

Table 6 - Mean values of meteorological parameters for each measuring period

\begin{tabular}{|c|c|c|c|c|}
\hline Razdoblje mjerenja & Statistički parametar & $\begin{array}{c}\text { Temperatura } \\
T /{ }^{\circ} \mathrm{C}\end{array}$ & $\begin{array}{c}\text { Relativna vlažnost } \\
\qquad R V / \%\end{array}$ & $\begin{array}{l}\text { Tlak } \\
p / \mathrm{hPa}\end{array}$ \\
\hline \multirow{3}{*}{ Z } & minimum & 2,2 & 52,7 & 1003,8 \\
\hline & maksimum & 14,4 & 88,5 & 1036,2 \\
\hline & srednja vrijednost & 7,9 & 70,7 & 1017,7 \\
\hline \multirow{3}{*}{$P$} & minimum & 4,6 & 56,7 & 1009,5 \\
\hline & maksimum & 17,8 & 90,1 & 1032,7 \\
\hline & srednja vrijednost & 12,3 & 72,1 & 1018,5 \\
\hline \multirow{3}{*}{ LJ } & minimum & 18,1 & 46,9 & 1003,9 \\
\hline & maksimum & 29,8 & 87,5 & 1021,3 \\
\hline & srednja vrijednost & 23,9 & 65,9 & 1013,9 \\
\hline \multirow{3}{*}{ J } & minimum & 5,2 & 57,9 & 1001,7 \\
\hline & maksimum & 15,9 & 93,6 & 1029,4 \\
\hline & srednja vrijednost & 10,4 & 83,3 & 1019,3 \\
\hline
\end{tabular}

Tablica 7 - Pearsonovi koeficijenti korelacije između mjerenih meteoroloških parametara i onečišćujućih tvari u zraku (statistički značajne korelacije označene su podebljanim fontom, $p<0,05$ )

Table 7 - Pearson correlation coefficients between measured meteorological parameters and air pollutants (statistically significant correlations are marked in bold, $\mathrm{p}<0.05)$

\begin{tabular}{|c|c|c|c|c|c|c|c|}
\hline \multirow[b]{2}{*}{ Sezona } & \multirow[b]{2}{*}{$\begin{array}{c}\text { Meteorološki } \\
\text { parametar }\end{array}$} & \multicolumn{3}{|c|}{ Biologija-sjever } & \multicolumn{3}{|c|}{ Biologija-jug } \\
\hline & & $\mathrm{H}_{2} \mathrm{~S}$ & $\mathrm{R}-\mathrm{SH}$ & $\mathrm{NH}_{3}$ & $\mathrm{H}_{2} \mathrm{~S}$ & $\mathrm{R}-\mathrm{SH}$ & $\mathrm{NH}_{3}$ \\
\hline \multirow{3}{*}{ Z } & $T$ & $-0,522$ & 0,127 & 0,412 & 0,971 & 0,977 & 0,808 \\
\hline & $R V$ & 0,421 & $-0,065$ & $-0,181$ & 0,495 & 0,488 & 0,391 \\
\hline & $p$ & 0,405 & $-0,186$ & $-0,239$ & $-0,995$ & $-0,998$ & $-0,846$ \\
\hline \multirow{3}{*}{$\mathrm{P}$} & $T$ & 0,421 & 0,083 & $-0,076$ & 0,978 & 0,976 & 0,980 \\
\hline & $R V$ & 0,345 & 0,012 & $-0,225$ & 0,468 & 0,469 & 0,414 \\
\hline & $p$ & $-0,631$ & $-0,134$ & $-0,018$ & $-0,999$ & $-0,999$ & $-0,983$ \\
\hline \multirow{3}{*}{ LJ } & $T$ & $-0,113$ & $-0,365$ & 0,365 & $-0,186$ & $-0,092$ & 0,566 \\
\hline & $R V$ & 0,081 & $-0,028$ & $-0,192$ & 0,196 & $-0,169$ & $-0,202$ \\
\hline & $p$ & 0,463 & $-0,049$ & $-0,273$ & 0,305 & $-0,190$ & 0,047 \\
\hline \multirow{3}{*}{$J$} & $T$ & 0,223 & $-0,532$ & $-0,131$ & $-0,171$ & $-0,494$ & $-0,091$ \\
\hline & $R V$ & $-0,174$ & 0,140 & $-0,100$ & 0,284 & 0,276 & $-0,138$ \\
\hline & $p$ & $-0,028$ & $-0,439$ & 0,001 & 0,002 & $-0,347$ & 0,040 \\
\hline \multirow{3}{*}{$\begin{array}{l}\text { sva razdoblja } \\
\text { mjerenja }\end{array}$} & $T$ & 0,686 & 0,738 & 0,680 & 0,716 & 0,736 & 0,608 \\
\hline & $R V$ & 0,261 & 0,225 & 0,036 & 0,255 & 0,228 & 0,114 \\
\hline & $p$ & $-0,976$ & $-0,996$ & $-0,857$ & $-0,987$ & $-0,995$ & $-0,785$ \\
\hline
\end{tabular}


a) $\mathbf{Z}$

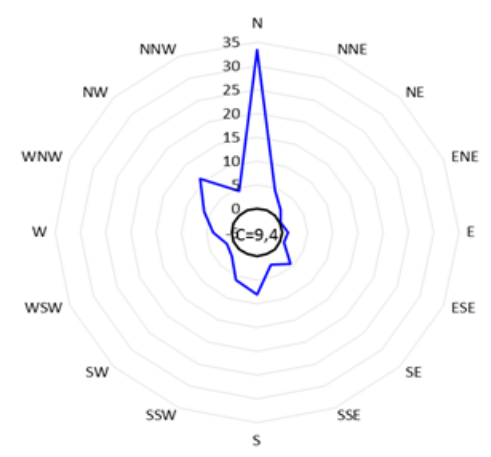

b) $\mathbf{P}$

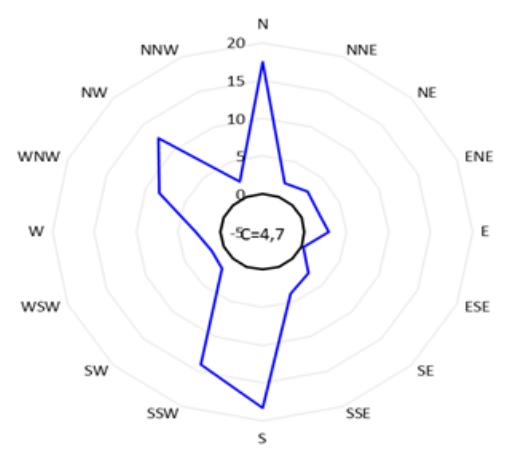

c) LJ

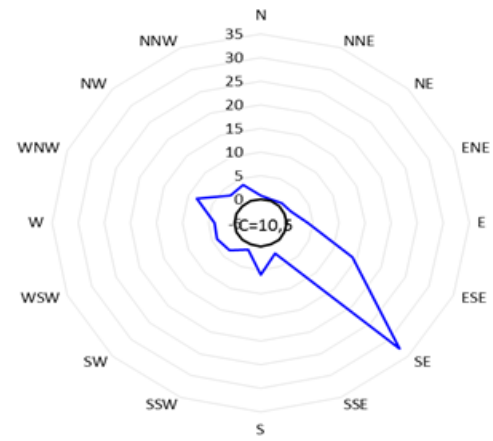

d) J

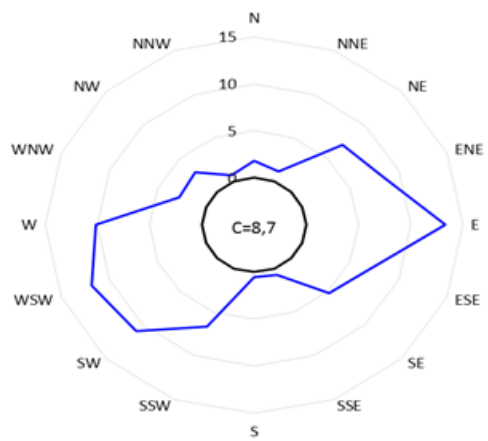

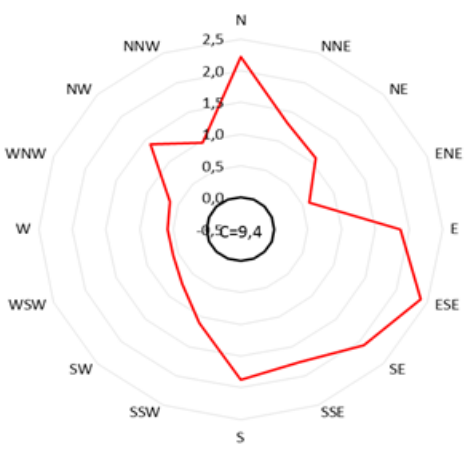
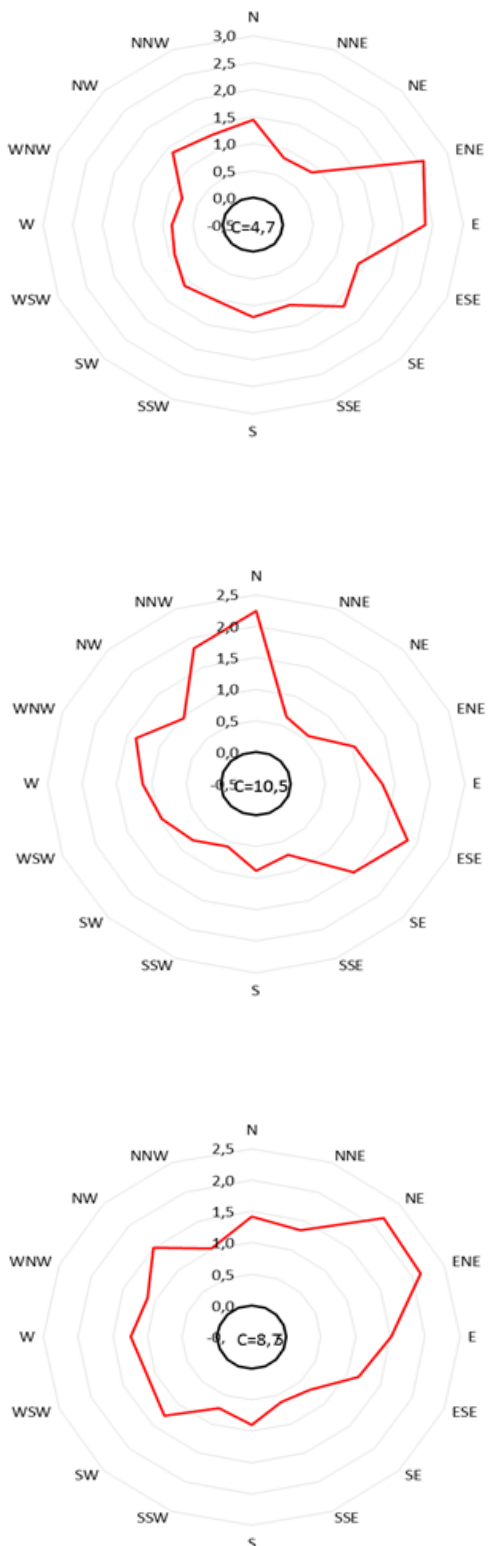

Slika 5 - Učestalost smjera vjetra [\%] (slike lijevo) i srednje vrijednosti brzine vjetra [ $\mathrm{m} \mathrm{s}^{-1}$ ] (slike desno) po smjerovima na mjernoj postaji Biologija-sjever određeni tijekom razdoblja mjerenja u 2017. godini

Fig. 5 - Frequency of wind direction [\%] (left figures) and mean values of wind speed $\left[\mathrm{m} \mathrm{s}^{-1}\right]$ (right figures) by directions at Biology-north determined during the measuring periods in 2017 
$\mathrm{H}_{2} \mathrm{~S}$ je statistički značajno korelirao sa svim meteoroloških parametrima u zimi te $\mathrm{s}$ tlakom zraka u proljeće i ljeto i temperaturom u proljeće. Merkaptani su statistički značajno negativno korelirali s temperaturom u ljeto i jesen te $\mathrm{s}$ tlakom u jesen. Amonijak je statistički značajno pozitivno korelirao s temperaturom zimi i ljeti. U zimskom i proljetnom razdoblju na području pročišćivača izmjerena je i veća učestalost vjetrova iz smjera sjevera i juga, pa se ne može isključiti utjecaj lokalnih izvora iz neposredne blizine.

Promatrajući sva mjerna razdoblja zajedno, na obje mjerne postaje pronađena je statistički značajna pozitivna korelacija između svih onečišćujućih tvari i temperature te sumporovodika i merkaptana s relativnom vlažnosti zraka. Statistički značajnu negativnu korelaciju s tlakom, na obje mjerne postaje, pokazuju sva mjerena onečišćenja. $\mathrm{Na}$ obje mjerne postaje između amonijaka i relativne vlažnosti nije uočena statistički značajna korelacija.

Zamijećena je manja razlika između maksimalne i minimalne vrijednosti meteoroloških parametara tijekom ljetne sezone mjerenja u usporedbi s ostalim sezonama. Ujednačenije vrijednosti meteoroloških parametara tijekom ljetnog razdoblja mjerenja u kombinaciji s niskim vrijednostima izmjerenih razina koncentracija $\mathrm{H}_{2} \mathrm{~S}$ i merkaptana vjerojatno kao posljedicu imaju i nisku razinu korelacije tijekom tih razdoblja mjerenja. Može se očekivati da neki drugi čimbenici kao što su aktivnost izvora ili smjer vjetra više doprinose promjenama razina koncentracija nego same vrijednosti meteoroloških parametara. S druge strane, masene koncentracije amonijaka nisu bile znatno niže ljeti u odnosu na ostala razdoblja mjerenja te je zamijećena statistički značajna korelacija razina amonijaka s temperaturom na oba mjerna mjesta. Porast temperature $u$ pravilu pospješuje isparavanje plinovitih onečišćenja u zraku. Pri stabilnim uvjetima niskog tlaka onemogućeno je razrjeđenje onečišćujućih tvari u zraku. Također, u uvjetima visoke relativne vlažnosti očekuje se zadržavanje onečišćenja koagulacijom u tekuću fazu aerosola i pojava magle onečišćene navedenim aerosolom.

\section{Zaključak}

Rezultati mjerenja masenih koncentracija sumporovodika, merkaptana i amonijaka provedenih tijekom 2017. godine na dvije mjerne postaje u krugu Centralnog uređaja za pročišćavanje otpadnih voda grada Zagreba pokazali su značajnu sezonsku ovisnost koncentracija onečišćujućih tvari. Uočene su statistički značajne korelacije između meteoroloških parametara (temperatura, relativna vlažnost, tlak) i mjerenih plinovitih onečišćujućih tvari u svim mjernim razdobljima, izraženije na mjernoj postaji
Biologija-jug. Promatrajući ukupno razdoblje, statistički značajne pozitivne korelacije na obje mjerne postaje uočene su između svih plinovitih onečišćujućih tvari i temperature, a negativne s tlakom zraka. Također, sve tri onečišćujuće tvari korelirale su pozitivno s relativnom vlažnosti zraka, ali za amonijak korelacija nije bila statistički značajna.

24-satne vrijednosti koncentracija $\mathrm{H}_{2} \mathrm{~S}$ na obje mjerne postaje u zimskom i jesenskom razdoblju povremeno su prekoračivale propisani GV, odnosno povremeno je dolazilo do dodijavanja neugodnim mirisom sumporovodika. Razine amonijaka bile su znatno niže od GV-a tijekom svih razdoblja mjerenja, dok su koncentracije merkaptana prekoračile GV jedino tijekom dva dana zimi na jednoj mjernoj postaji.

\section{ZAHVALA}

Mjerenja $\mathrm{H}_{2} \mathrm{~S}, \mathrm{NH}_{3}$ i R-SH i meteoroloških parametara prikazana u ovom radu financirana su $\mathrm{i}$ provedena temeljem Ugovora sa Zagrebačkim otpadnim vodama Upravljanje i pogon d.o.o., kojima zahvaljujemo na ustupanju podataka u znanstvene svrhe. Zahvaljujemo dr. sc. Marinu Ganjtu na pomoći pri izradi ovog rada.

\section{Literatura \\ References}

1. URL: https://www.zagreb.hr/o-zagrebu/1081 (12. 3. 2020.).

2. URL:

https://www.pmf.unizg.hr/images/50017753/brosura\%20ure djaj\%20zagreb.pdf (12. 3. 2020.).

3. I. Banić, Obrada i zbrinjavanje mulja s uređaja za pročišćavanje otpadnih voda, Istarsko veleučilište, završni rad, 2017., URL: https://repozitorij.politehnikapula.hr/islandora/object/politehnikapu\%3A100 (31. 3. 2020.).

4. Vlada RH, Pravilnik o graničnim vrijednostima emisija otpadnih voda NN 026 (2020) URL: https://narodnenovine.nn.hr/clanci/sluzbeni/full/2020_03_26_622.html (26. 3. 2020.).

5. WHO, Environmental Health Criteria 54 'Ammonia', 1986., Geneva, Switzerland.

6. V. Vađić, M. Gentilizza, J. Hršak, M. Fugaš, Determination of Hydrogen Sulphide in the Air, Staub Reinhalt Luft 40 (1980) 73

7. V. Vađić, Metoda za određivanje $\mathrm{H}_{2} \mathrm{~S}$ u atmosferi, Zašt. Atm. 10 (1982) 116.

8. H. B. A. Moore, H. L. Helwig, R. J. A. Graul, Spectrophotometric Method for the Determination of Mercaptans in Air, Am. Ind. Hyg. Assoc. J. 21 (1960) 466468, doi: https://doi.org/10.1080/00028896009344106.

9. Vlada RH, Uredba o razinama onečišćujućih tvari u zraku, NN 117 (2012), URL: https://narodnenovine.nn.hr/clanci/sluzbeni/2012_10_117_2521.html. 
10. WHO, Evolution of WHO air quality guidelines: past, present and future, European Environment and Health Process, 2017., URL:

http://www.euro.who.int/_data/assets/pdf_file/0019/33166 0/Evolution-air-quality.pdf.

11. N. Kalinić, V. Vađić, M. Čačković, A. Šišović, K. Šega, I. Bešlić, Levels of specific air pollutants characterized by annoying odour, Proc. $14^{\text {th }}$ International Union of Air Pollution Prevention and Environmental Protection Associations (IUAPPA) World Congress 2007, $18^{\text {th }}$ Clean Air Society of Australia and New Zealand (CASANZ) Conf., (2007) 6 p.
12. IMI, Izvještaj o praćenju kvalitete zraka u zoni utjecaja CUPOVZ-a u Zagrebu, izvještaj IMI-P-404/2017, $2017 .$, URL:http://iszz.azo.hr/iskzl/godizvrpt.htm?pid=0\&t=2 3. 2020.).

13. Hrvatska agencija za okoliš i prirodu web portal Kvaliteta zraka u RH, URL:

http://iszz.azo.hr/iskzl/godizvrpt.htm?pid=0\&t=2 (12. 3 . 2020.).

14. R. Godec, G. Pehnec, V. Vađić, Razine vodikovog sulfida i merkaptana u zraku na području CUPOVZ-a, Zaštita okoliša i održivo gospodarenje resursima, 2014., str. 271-276.

\title{
SUMMARY
}

\section{Levels of Hydrogen Sulphide, Ammonia, and Mercaptans in the Air of the Central Wastewater Treatment Plant Zagreb Area}

\author{
Valentina Gluščić, Martina Šilović Hujić, Ivan Bešlić, Silvije Davila, and Gordana Pehnec
}

Since 2004, continuous measurements of hydrogen sulphide $\left(\mathrm{H}_{2} \mathrm{~S}\right)$, ammonia $\left(\mathrm{NH}_{3}\right)$, and mercaptan $(\mathrm{R}-\mathrm{SH})$ levels in air have been monitored in the area of the Central wastewater treatment plant Zagreb (CUPOVZ). At two measuring sites within the CUPOVZ area, Biology-north and Biology-south, for a month in every season in 2017, twenty-four hour samples of $\mathrm{H}_{2} \mathrm{~S}, \mathrm{NH}_{3}$, and $\mathrm{R}-\mathrm{SH}$ were collected. Measured concentrations of gaseous pollutants showed statistically significant seasonal variations $(p<0.05)$ at both measuring stations. For the overall period, high positive correlations were found between all pollutants and temperature, and negative with pressure.

\section{Keywords}

Wastewater treatment plant, measuring site, immissions, limit value, seasonal variations, correlations 